UDC 336:338

JEL Classification: R13

DOI: 10.15587/2706-5448.2021.229787

Article type «Reports on Research Projects»

\section{Tetiana Dedilova, Iaroslava Levchenko, Oleksandr Nosyriev, Svitlana Osypova}

\title{
JUSTIFICATION OF REGIONAL DEVELOPMENT OF INDUSTRIAL ENTERPRISES IN THE PLANE OF THEIR FINANCIAL SUPPORT: EXPERIENCE OF UKRAINE
}

The object of research is the regional industry of Ukraine. In the sectoral context, the general structure of the regional industry is significantly deformed, and the strategic and sectoral guidelines of economic policy are blurred, which makes it difficult to restore the economic growth of the country as a whole. The industrial potential is concentrated mainly in traditional industrial regions. The development of industry is hampered by the wornout state of the technical and technological base of production, a high level of staff turnover, an insignificant percentage of the production of high-tech products, a lack of institutions for innovative development, and similar factors. The complexity of the procedures for financing the processes of industrial development is mediated by the innovative activity of its subjects. The processing industry is the central center of innovation in the industry. Among the sources of financing for innovations, enterprises' own funds prevail.

It is substantiated that the main directions of regional development of industrial enterprises in terms of financial support for their functioning are support and encouragement of innovation, measures to increase the competitiveness of industrial products, internationalization and support for exports. It is proved that the regions of the country unevenly use the mechanisms of investment support for industry, depending on the characteristics of the development of the regional economy. This necessitates the creation of investment mechanisms aimed at ensuring the management of the competitiveness of regional industrial complexes on the basis of the development and implementation of innovations. A multichannel investment mechanism has been proposed to ensure a full-fledged infusion of financial resources from several sources as an effective tool for financial influence on the development of industrial enterprises. It is noted that among the directions of development of industrial management should remain both traditional measures to support domestic producers (state regional purchases) and alternative (financial leasing, initial placement of securities, joint investment). For a separate direction of industrial development, it is recommended that state support of cluster interregional initiatives based on the use of leading European experience. The highlighted areas are relevant for potential foreign partners who intend to carry out joint business with Ukrainian industrial enterprises. Also, the indicated research results are significant in the process of attracting investments at the regional level and have practical value for foreign investors when they consider a portfolio of alternatives to foreign direct investment in Ukrainian industrial facilities.

Keywords: industrial enterprise, industrial policy, regional industry of Ukraine, financial resources, innovative development.

How to cite

Dedilova, T., Levchenko, I., Nosyriev, O., Osypova, S. (2021). Justification of regional development of industrial enterprises in the plane of their financial support: experience of Ukraine. Technology Audit and Production Reserves, 2 (4 (58)), 33-37. doi: http://doi.org/10.15587/2706-5448.2021.229787

\section{Introduction}

The current state of the economy and market realities determine a number of problematic issues in the field of financing the activities of industrial enterprises, increasing the level of their competitiveness, using methods and tools of strategic management, ensuring investment attractive- ness. In these conditions, the issues of the formation and implementation of an effective industrial policy, including the industrial policy of the regions, acquire special relevance. It is industrial policy that is the basis for the economic development of the state in symbiosis with innovative structural shifts and effective financing mechanisms. The financial stability of industrial enterprises is an equilibrium 
state, being in which they are able to form financial resources in sufficient volume and ensure socio-economic development, promptly respond to changes in market conditions.

Crisis phenomena are an integral part of the life cycle of an enterprise, the aggravation of which has recently inflicted a significant blow on the activities of industrial manufacturers. The global pandemic COVID-19 causes the search on the part of business entities for new ways to solve the problems of industrial development in conditions of limited financial resources, including at the regional level.

The relevance of such questions has been confirmed by a number of studies by modern scientists. In particular, the work [1] notes the need to move from the use of industrial policy to the use of competition policy. At the same time, it is industrial policy that is the defining principle of reforming regional development in the context of the volatility of the external environment. In addition, using the example of China, the authors of the study [2] proved that enterprises are more likely to invest in regions that are supported by industry policies. Thus, there is an imbalance in the financing of the regions, the essence of which is that the higher the level of financing in the region of the enterprise's presence, the greater the likelihood of its interregional investments. It was also noted that the promotion of regional industrial renewal through sectoral policy should be based on the company's compliance with market rules for the implementation of market-oriented investments.

As for the European experience in the development of industrial enterprises, scientists are also not unambiguous in their thoughts. Thus, work [3] is devoted to the consideration of regional industrial restructuring in the context of economic geography. This approach makes it possible to link the regional development of industrial enterprises with the unevenness of their sectoral affiliation and territorial distribution.

In contrast, the authors of the study [4] are supporters of an innovative approach to the regional development of industrial enterprises in the countries of the European Union. In particular, they note that innovation policy is inextricably linked with industrial policy in the state and its regions. It allows the use of traditional measures to support national producers - regional public procurement as a tool for institutionalizing public administration - among the main directions of industrial management development.

Along with traditional methods [5], alternative methods of managing the development of industrial enterprises are distinguished, aimed at solving financial problems arising in the context of the global economic crisis (venture capital, private capital, etc.). This approach is of particular relevance due to the spread of the Corona crisis and its consequences for the business environment of these enterprises. In [6], it is noted that in the formation of post-COVID-19 society, a turning point has already been reached between industrial policy, sustainability and the development of industrial enterprises by rethinking their management processes. At the same time, the authors of [6] see the role of industrial policy not only in the positive dynamics of gross output, but also in its participation in the sustainable development of society.

Analysis of the activities of industrial enterprises in the context of their participation in the formation of European exports allows to single out an approach focused on the macroeconomic aspect. The team of authors [7] notes that it is the contribution of industry to export activities associated with weaknesses in production that leads to structural external imbalances and determines the characteristic features of the European economy. Thus, the authors associate regional and global value chains with the concept of «peripheral economy». The distribution of European countries in terms of production development is based on the criterion of the economy with a low/middle income level. According to the study [7], it is to such a group of countries that Ukraine belongs as a part of the cluster of countries of Southern Europe, the Western Balkans, and others. They are characterized by an insignificant contribution to export activities.

This position of Ukraine in the international division of industrial production determines the search by Ukrainian scientists for ways to solve the issues of forming and assessing the financial strategy and financial potential of an industrial enterprise. The analysis of recent studies and publications of Ukrainian scientists on the designated topics allowed to conclude that further in-depth development of the theory, methodology and practice of financing such enterprises in the context of the industrial policy of the regions is necessary [8-10].

Thus, the object of research is the regional industry of Ukraine. The aim of research is to identify trends and directions of regional development of industrial enterprises on the example of Ukraine in terms of financial support for their functioning.

\section{Methods of research}

During the research, the following scientific methods were used:

- method of analysis (when studying the structure of the financial potential of industrial enterprises by the scale of industrial policy and identifying areas for financing innovative activities in industry);

- method of theoretical generalization (to identify the research problem and form conclusions based on its results);

- statistical methods of information processing (when analyzing the volume of sales of industrial products by regions of Ukraine, indices of industrial products, volumes of investment in innovations in industry); - graphic methods (for visualization and visual display of the results of the analysis of statistical data on the activities of industrial enterprises in Ukraine).

\section{Research results and discussion}

The industrial policy of the state is based on the system of financial and organizational relations between business entities, government bodies, scientific institutions and public organizations, the balanced interaction of which leads to the formation of a stable synergistic effect. This effect can be considered as the functioning of a competitive industry, ensures the economic growth of regions and the state as a whole.

According to the Reports of the National Academy of Sciences of Ukraine [11], Ukraine today has neither a strategy for modernizing its own industry, nor any regional or sectoral industrial development programs. Strategic and sectoral guidelines for economic policy are blurred, which seriously complicates the recovery of economic growth. This trend has a significant impact on the prioritization 
of government bodies in the allocation of budget funding, as well as on the development of strategies for their development on the part of enterprises. In addition, in [12], the author notes the lack of information and statistical analysis tools for high-tech production, a unified classifier of this kind of products. This poses obstacles in the setting of priorities among the industries, their further support and financing from the state.

In the regional context, industrial workload has an unbalanced structure, causing:

- their uneven economic and social development;

- carries risks of man-made safety;

- shifts the balance in the consumption of industrial resources in favor of a particular region;

- orients individual territories to the raw materials and processing industry, costly type of production, and the like.

In recent years, industrial potential has been concentrated mainly in industrial regions, which include Dnipropetrovsk, Donetsk, Zaporizhzhia, Poltava, Kharkiv, Kyiv and Lviv regions (Fig. 1).

Based on the analysis of Fig. 1, in the total volume of sold industrial products in 2020 , their share was $58.23 \%$. At the same time, regions with a low level of industrial development in 2020 accounted for only $8.56 \%$.

So, according to the State Statistics Service in 2020 compared to 2019, the industrial production index was $94.8 \%$ (Fig. 2). In particular, in the mining and quarrying industries this indicator was $96.9 \%$, in the processing industry - $93.1 \%$, in the supply of electricity, gas and conditioned air $98.7 \%$ [13]. Thus, in the sectoral context, the overall structure of the industry is significantly deformed. This is due to the low share of high-tech products and the low added value of other types of products.

This deformation is also present in the opinion of the author of work [14], who also indicates the presence of negative trends in the innovation activity of Ukrainian industrial enterprises as a result of these trends. The protracted economic crisis, characteristic of the last years of the functioning of the Ukrainian economy, led to a decrease in the innovative activity of industrial entities due to a lack of necessary funding, institutional imbalances, low investment attractiveness, etc. Based on research [15], in addition to the above signs of a decline in the innovation sphere, these include a low degree of renewal of the basic production assets of industry, a lack of highly qualified labor force, lack of motivation among workers, an insignificant percentage of high-tech products, and the like.

These factors generally characterize a disappointing picture of the development of industry in the regions, while regional competitiveness is able to ensure sustainable socio-economic development of Ukraine in the long term. It is the competitiveness of the industrial production of the regions that is achieved through the growth of the gross value added of innovative products, the renewal of the technical and technological base of the subjects of production activity, and the attraction of additional sources of financing for innovations.

Until now, the financing of innovation processes for certain types of industrial activity in Ukraine is characterized by a shift in proportions in favor of the processing industry. In particular, there is a distribution of funds for the implementation of innovations in the field of mechanical engineering, food technologies, the chemical industry and pharmacy, the metallurgical industry, etc. However, such financing does not testify in favor of the development of high-tech innovative products, but the predominance of financial resources for financing medium- and low-tech products. ... So, from the lack of funds, first of all, the production associated with high technologies suffers, and it also indicates an unbalanced structure of industry in the regions [16].

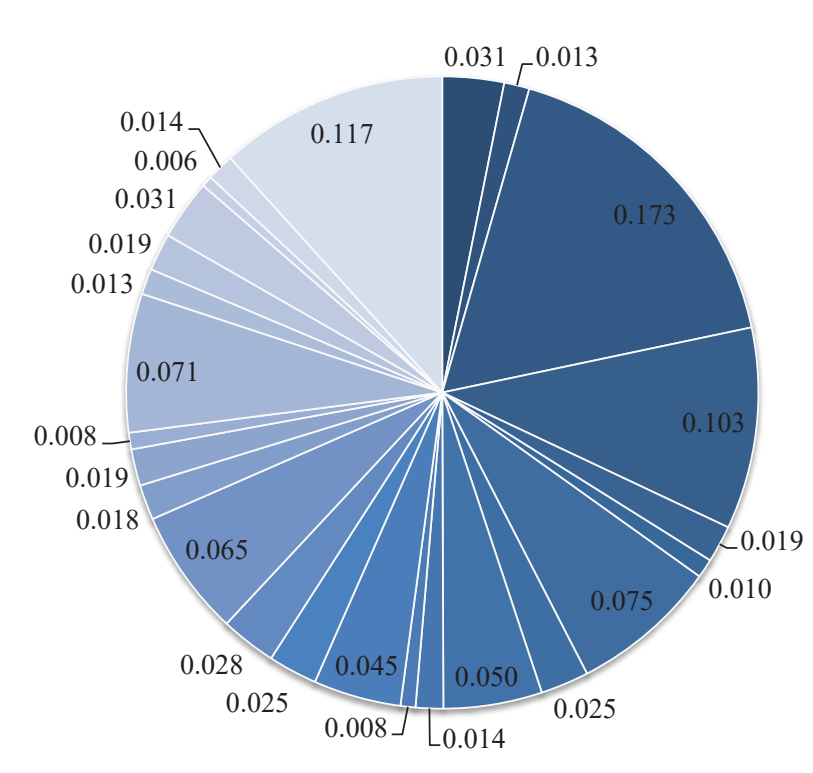

Fig. 1. The volume of industrial products sold by region in 2020 (built by the authors according to [13])

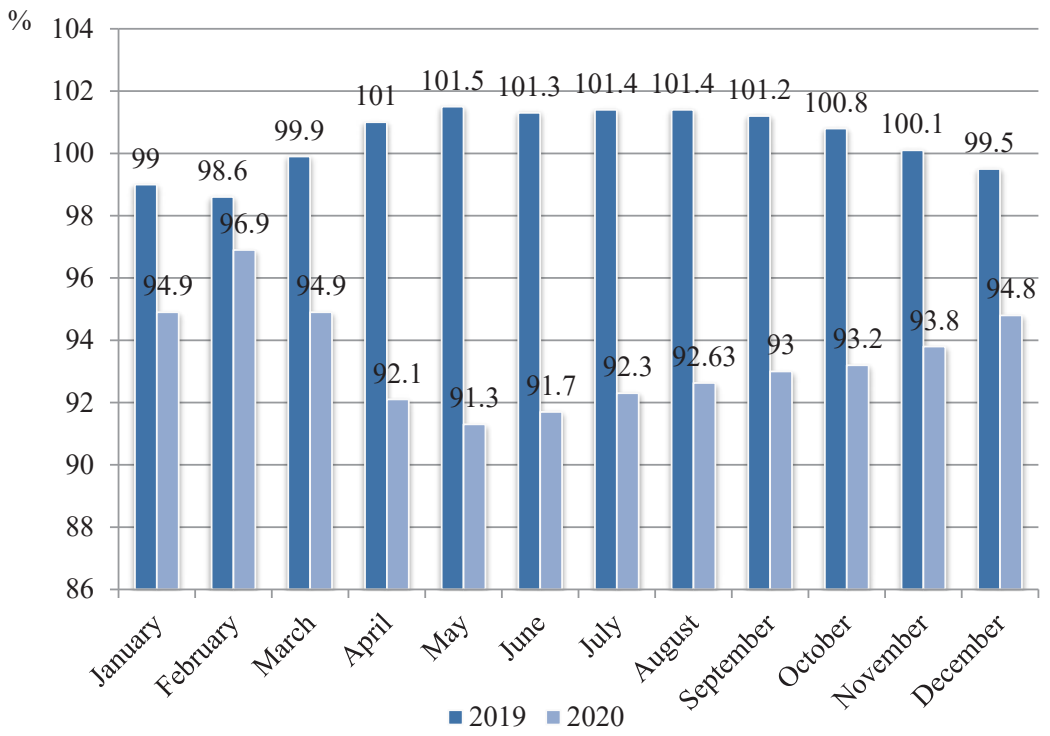

Fig. 2. Indices of industrial production (constructed by the authors according to [13]) 
Self-financing prevails among the sources of financing for innovation, which is explained by the reluctance of investors to invest in high-tech businesses with significant innovation risks (Fig. 3). This is also due to the lack of investment stability and a well-developed mechanism for insuring investors' risks, the interest of financial institutions in the development of the real sector of production.

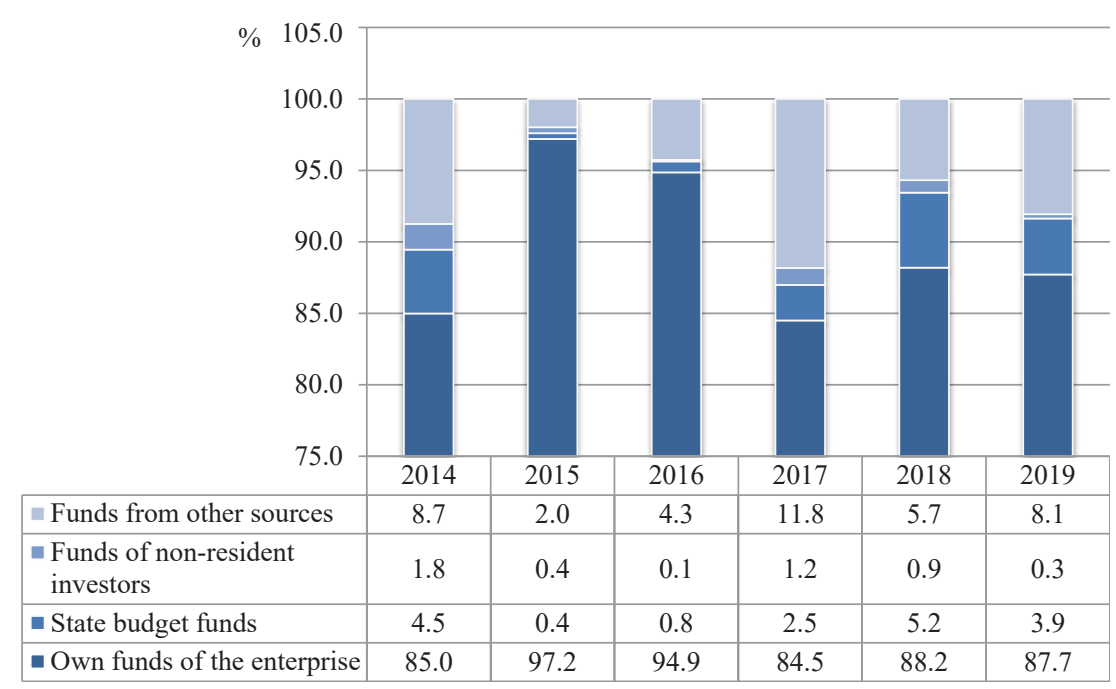

Fig. 3. The structure of financing innovations in industry (Constructed by the authors from [17])

The strategic development of industrial enterprises cannot be imagined without the implementation of a solid financial strategy. Rational distribution of financial resources in the short and long term allows to prioritize innovative projects in accordance with the established goals. In addition, the financial strategy is an integral part and the most important element in the system of strategic development management both at the enterprise level and at the level of industries and in the regional context. The financial strategy defines the principles of the enterprise for the formation of financial reserves, with its help it is possible to evaluate the results of current work and develop management decisions regarding future directions of activity [18].

The implementation of an effective financial strategy takes place through the use of the existing financial potential of an industrial enterprise. Financial potential management is a purposeful management impact on financial resources to achieve financial well-being and increase its level for the development and recovery of production based on innovation.

The financial potential should be considered as the most important strategic tool for the sustainable development of industrial enterprises, due to the existing structure of their financial resources. This structure does not significantly affect production efficiency in the medium and long term and, thus, does not allow assessing the possibilities of using the financial potential of the enterprise [19].

As for the financial potential of the region, at the level of regional management and from the standpoint of industrial policy, it can be considered as the aggregate ability of industrial entities to form, distribute and use financial resources. The generation and use of such resources allow local governments to directly implement the functions of ensuring the social and economic development of the region. At the same time, the fundamental fact is whether these resources are at the disposal of enterprises, or they are supposed to be available in the planning period. So, the financial potential of the region directly depends on the attraction of investment resources, including in industrial facilities. This task is of primary importance specifically for regional industrial complexes, whose activities are capable of influencing the competitiveness of the national economy as a whole. The implementation of this task should take into account the specifics of the mechanisms of industrial investment at the regional level, as well as the level of strategic management of the financial strategy of business entities [20].

Prioritization of investment in industrial facilities should be based on the concentration of financial resources in exactly the direction that will meet an effective industrial regional policy. Financial flows generated by high-tech industries will help create a new level of production infrastructure aimed at ensuring a competitive Ukrainian industry in the world market.

\section{Conclusion}

Thus, according to the results of the study, the following conclusions can be drawn about identifying trends and directions of regional development of industrial enterprises in Ukraine in terms of financial support for their functioning: - in countries with highly developed modern economies, industrial growth is programmable, which is ensured through the formation and implementation of an appropriate industrial policy. In Ukraine, the formation of such a policy is open and one that would be based on responsible personnel, innovation, financial, marketing strategies in the field of promoting competitive relations. Promising areas of regional industrial policy should be support and encouragement of innovative activities of industrial enterprises, measures to increase the competitiveness of industrial products, internationalization and support for exports;

- the regions of the country unevenly use one or another mechanism of investment support for industry, depends, first of all, on the peculiarities of the development of the regional economy. In these conditions, it is advisable to create investment mechanisms aimed at ensuring the management of the competitiveness of regional industrial complexes on the basis of the development and implementation of innovations;

- an effective tool for financial impact on the development of industrial enterprises should be the development of a multi-channel investment mechanism to ensure a fullfledged infusion of financial resources from several sources; - among the directions of the development of industrial management should remain both Traditional measures to support domestic producers - government procurement at the regional level, and alternative ones. These include the implementation of joint investment projects, financial leasing, outsourcing, positioning in the stock market; - for a separate area of industrial development, it is advisable to implement state support for cluster interregional initiatives based on the use of the leading European experience of neighboring states (industrial parks in Poland and Slovakia); 
- the above directions can be used in the formation of a strategic investment portfolio of a foreign investor, such as considers foreign direct investment in the Ukrainian economy as a prospect of investment funds. In addition, when justifying joint business projects of Ukrainian and foreign partners, it is advisable to take into account such areas, relying on the results of an analysis of industry and regional features of the development of production facilities.

\section{References}

1. Tian, G. (2020). From industrial policy to competition policy: A discussion based on two debates. China Economic Reviere, 62, 101505. doi: http://doi.org/10.1016/j.chieco.2020.101505

2. Dai, Y., Hou, J., Li, X. (2021). Industry policy, cross-region investment, and enterprise investment efficiency. Research in International Business and Finance, 56, 101372. doi: http:// doi.org/10.1016/j.ribaf.2020.101372

3. Jolly, S., Grillitsch, M., Hansen, T. (2020). Agency and actors in regional industrial path development. A framework and longitudinal analysis. Geoforum, 111, 176-188. doi: http:// doi.org/10.1016/j.geoforum.2020.02.013

4. Uyarra, E., Zabala-Iturriagagoitia, J. M., Flanagan, K., Magro, E. (2020). Public procurement, innovation and industrial policy: Rationales, roles, capabilities and implementation. Research Policy, 49 (1), 103844. doi: http://doi.org/10.1016/j.respol.2019.103844

5. Kádárová, J., Bajus, R., Rajnoha, R. (2015). Optimal Financing of the Industrial Enterprise. Procedia Economics and Finance, 23 953-958. doi: http://doi.org/10.1016/s2212-5671(15)00380-9

6. Ferrannini, A., Barbieri, E., Biggeri, M., Di Tommaso, M. R. (2021). Industrial policy for sustainable human development in the post-Covid19 era. World Development, 137, 105215. doi: http:// doi.org/10.1016/j.worlddev.2020.105215

7. Landesmann, M. A., Stöllinger, R. (2019). Structural change, trade and global production networks: An «appropriate industrial policy» for peripheral and catching-up economies. Structural Change and Economic Dynamics, 48, 7-23. doi: http://doi.org/ 10.1016/j.strueco.2018.04.001

8. Vlasova, N. O. (2018). The Effect of Macroeconomic Factors on the Financial Results of Industrial Enterprises. Social Economics, 56, 18-26. doi: http://doi.org/10.26565/2524-2547-2018-56-2

9. Mishchenko, D. A., Mishchenko, L. O., Kholoshnya, D. O. (2017) State financial support of industrial development of Ukraine as a method of overcoming the financial crisis. Economy and state, $11,15-20$.

10. Nosyriev, O., Dedilova, T., Osypova, S. (2020). Financial instruments in the system of competitiveness of regional industrial complexes. Problemy i perspektyoy rozvytku pidpryiemnytstva, 2 (25), 93-108. doi: http://doi.org/10.30977/ppb.2226-8820.2020.25.0.93

11. Deineko, L. V. (Ed.) (2019). Promyslova polityka yak kliuchovyi instrument stratehii rozoytku. Kyiv: NAN Ukrainy, DU «In-t ekon. ta prohnozuv. NAN Ukrainy». Available at: http://ief.org.ua/ docs/sr/304.pdf
12. Pushkarchuk, I. M. (2016). Mechanisms for increasing the competitiveness of industry as a basis for financial stabilization of the regional economy. Efficient economy, 3. Available at: http://nbuv.gov.ua/UJRN/efek_2016 3 40

13. Ekonomichna statystyka. Ekonomichna diialnist. Promyslovist: statystychna informatsiia. Derzhavna sluzhba statystyky Ukrainy. Available at: http://www.ukrstat.gov.ua/

14. Radziwill, I. V. (2010). Financial instruments for overcoming the crisis of innovative development of industrial enterprises. Economic Bulletin of the National Mining University, 3, 66-74. Available at: http://nbuv.gov.ua/UJRN/evngu_2010_3_12

15. Obolentseva, L. V. (2017). The Methods of Formation of a Strategy of Competitiveness Management of the Industrial Complexes of Regions. Biznes Inform, 12, 413-418. Available at: http://nbuv.gov.ua/UJRN/binf_2017_12_65

16. Shovkun, I. A. (2014). Financial support of innovative activity in the context of neoindustrialization of economy of Ukraine. Finance of Ukraine, 12, 83-95. Available at: http://nbuv.gov.ua/ $\mathrm{UJRN} / \mathrm{Fu} 2014 \_12 \_8$

17. Ekonomichna statystyka. Nauka, tekhnolohii ta innovatsii: statystychna informatsiia. Derzhavna sluzhba statystyky Ukrainy. Available at: http://www.ukrstat.gov.ua/

18. Savko, O. Ya. (2016). Classification of financial strategies of industrial enterprises. Naukovyi visnyk Uzhhorodskoho natsionalnoho universytetu: Seriia: Mizhnarodni ekonomichni vidnosyny ta svitove hospodarstvo, 8 (2), 79-82.

19. Maslak, O. I. (2014). Osoblyvosti otsiniuvannia finansovoho potentsialu promyslovoho pidpryiemstva. Visnyk KrNU imeni Mykhaila Ostrohradskoho, 6 (77), 124-129.

20. Demyanchuk, O. I. (2014). Financial potential of regions of Ukraine as a basic basis of their stable economic development. Scientific notes of the National University «Ostroh Academy». Series: Economics, 27, 73-78. Available at: http://nbuv.gov.ua/ UJRN/Nznuoa_2014_27_15.pdf

Tetiana Dedilova, PhD, Associate Professor, Department of Economics and Entrepreneurship, Kharkiv National Automobile and Highway University, Kharkiv, Ukraine, ORCID: https://orcid.org/0000-00023924-979X, e-mail: dedilova@ukr.net

Iaroslava Levchenko, PhD, Associate Professor, Department of Economics and Entrepreneurship, Kharkiv National Automobile and Highway University, Kharkiv, Ukraine, ORCID: https://orcid.org/ 0000-0002-4979-1101, e-mail: slavalevcenko1984@gmail.com

Oleksandr Nosyriev, PhD, Associate Professor, Department of International Business and Finance, National Technical University «Kharkiv Polytechnic Institute», Kharkiv, Ukraine, ORCID: https:// orcid.org/0000-0003-4089-3336, e-mail: nosyriev.bf@khpi.edu.ua

Svitlana Osypova, Department of International Business and Finance, National Technical University «Kharkiv Polytechnic Institute», Kharkiv, Ukraine, ORCID: https://orcid.org/0000-0002-9054-9499, e-mail: osipovask1@ukr.net 